\title{
Assessment of water balance for Badove Lake, Kosovo
}

\author{
S. Bublaku \& A. Beqiraj \\ Faculty of Geology and Mines, \\ Polytechnic University of Tirana, Albania
}

\begin{abstract}
This paper aims to evaluate the water balance for Badovc Lake, Kosovo based on the hydrological monitoring made in the period 2013-2014. The recent bathymetric data showed that the current maximum volume (corresponding to height of $649.75 \mathrm{asl}$ ) of the lake is $25,590,000 \mathrm{~m}^{3}$, being $1,000,000 \mathrm{~m}^{3}$ less than the initial volume due to the sedimentation on the lake bottom. The average annual rainfall in the dam was $860.7 \mathrm{~mm}$ being higher than its historical value $(642.0 \mathrm{~mm})$. The overall water inflow into the lake was $22,577,663 \mathrm{~m}^{3}$. The calculations of the evaporation rates showed that the annual amount of evaporation from the lake surface was $849,535 \mathrm{~m}^{3}$ or $644.50 \mathrm{~mm}$. During the dam design an annual infiltration rate of $94,608 \mathrm{~m}^{3}$ from the clay screen was assessed. Data on water intake showed that a quantity of $10,550,615 \mathrm{~m}^{3}$ was abstracted from the lake during 2014. Considering the above cited inflow and outflow quantities $\left(22,577,663 \mathrm{~m}^{3} 11,494,758 \mathrm{~m}^{3}\right.$, respectively), a residual water volume of 11,082,905 was evaluated. On the other hand, the positive volume of the lake in 2014, calculated according to water level variations, was $7,344,000 \mathrm{~m}^{3}$. A difference of 3,682,905 $\mathrm{m}^{3}$ between the above water volumes may be considered as "water loss" from the lake. This amount of water represents around $17 \%$ of the total volume of lake, or around $35 \%$ of its current water abstraction. The hydrologic balance of the lake watershed will further clarify the factors that are responsible for this "water loose" from the lake. In addition, the results of this study will help the authorities to better manage the water intake.
\end{abstract}

Keywords: lake water balance, annual rainfall, water inflow and outflow, water runoff, evaporation and infiltration. 


\section{Introduction}

Badove Lake was built in 1965 and its dam crosses Graçanka river flow, which is a branch of Sitnica River and belongs to Iber basin. The lake is originally built for agricultural irrigation and mining water supply, but after 1980 it was used for drinking water supply of Prishtina city and its surroundings.

Geological formations of the Badovc basin are represented by limestone, clastic formations, magmatic and metamorphic rocks, which are tectonised and fissured to different extent [1]. Dam is constructed mainly on a serpentinite basement which is plenty of cracks and fissures filled with kalcedon, opal, carbonates and clays. A tectonic zone dipping just vertically is developed beneath the dam [2]. Most of geological formations of the basin are characterized by low water permeability except karstic limestone.

The catchment area of Badove basin is about $104.1 \mathrm{~km}^{2}$ and lies from elevation 608 to $1200 \mathrm{~m}$ above sea level. It is characterized by a high vegetation cover that comprises around $90 \%$ of its surface.

The historical rainfall (1947-1994) was $647.36 \mathrm{~mm} \mathrm{[3],} \mathrm{whereas} \mathrm{the}$ monitored rainfall for 2014 was $859.95 \mathrm{~mm}$. The total water inflow and outflow for the year 2014 were 22,577,663 $\mathrm{m}^{3}$ and $11,494,758 \mathrm{~m}^{3}$, respectively. As from the variations of the lake water level, the change of lake water volume in 2014 was $7,344,000 \mathrm{~m}^{3}$. On the contrary, the inflow-outflow water balance in the lake showed a lack of $3,682,905 \mathrm{~m}^{3}$ water which is considered as a water loss from the lake. In addition, the water level in Hajvalia mine was raised around $114 \mathrm{~m}$ during the period 2004-2014 (from 386.0 masl in 2004 to 500 masl in 2014), while $\mathrm{pH}$ value of mine water was increased from 6.5 to around 7.0 [4]. Variation of above mentioned parameters favors the opinion of a possible hydraulic communication between the lake and mine which was stimulated from activation of the crack system by mine explosions.

\section{Materials and methods}

A digital Hydrographic Echo Sunder-HydroBox2010 device, with measuring frequency every $5 \mathrm{sec}$, was used for generating bathymetric data which were then interpolated by the Arc-GIS for the construction of the lake bathymetry. In 2013 four manual pluviometers with diameter $250 \mathrm{~mm}$ have been installed for a daily monitoring of the rainfall in the basin. A continuous geodesic survey was applied for the monitoring of water level variations in the lake. The evaluation of the rivers flow was made across hydrometric regular profiles, where the water speed was measured with Flowatch-JDC instrument. The daily abstraction of water from the lake was provided by water supplier of Prishtina. Evaporation rates were calculated based on the meteorological data provided by the Institute of Hydrometeorology of Kosova. Finally, changes in lake water volume we used to calculate the rate of groundwater inflow and outflow. 


\section{Description of basin}

\subsection{Location, topography and vegetation cover}

The catchment area of Badovc Lake is located in the north-eastern part of Kosovo, between $21^{\circ} 03^{\prime}$ e $21^{\circ} 23^{\prime}$ E and $42^{\circ} 40^{\prime}$ e $42^{\circ} 36^{\prime} \mathrm{N}$, fig. 1 . Its relief is mostly rugged and elevation ranges from 608 to $1200 \mathrm{~m}$ above sea level. The Badove basin comprises 7\% gentle slopping, 25\% undulating terrain, $42 \%$ rugged terrain and $26 \%$ steep mountains. It has a total area of $104.1 \mathrm{~km}^{2}$. Out of this $90 \%$ are forests, $5 \%$ are cultivated land, $1.5 \%$ is water and $1.5 \%$ construction area.

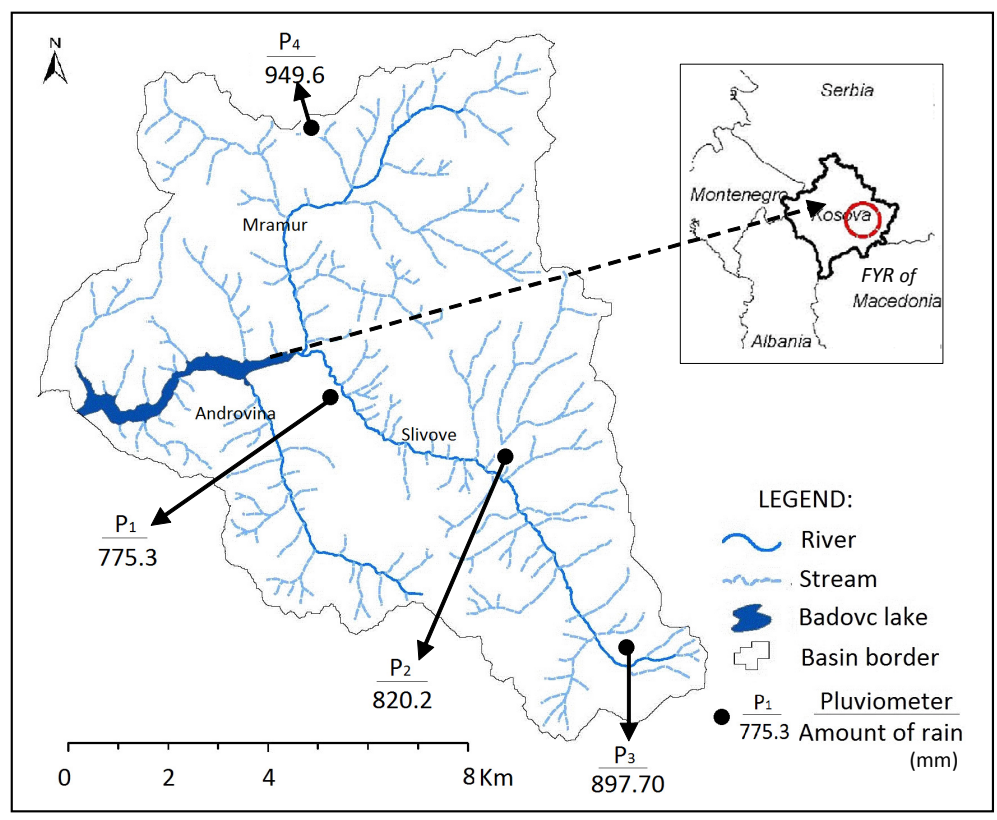

Figure 1: Hydrologic basin of Badove (hydrographic network and annual rainfall distribution for the year 2014 are shown).

Badovc catchment is characterized by a centripetal river patterns (Mramur, Slivovë and Androvina) that originate from surroundings highlands and drained towards the lake, fig. 1. The maximum values of surface and volume that correspond to highest water level in the lake, are $1.72 \mathrm{~km}^{2}$ and $25,590,000 \mathrm{~m}^{3}$, respectively.

\subsection{Climate}

The basin of Badovc Lake belongs to the continental climate [3], and is conditioned by both the relief of the region and the valley of Sitnica river. 
According to historical data [2] average annual rainfalls are $647 \mathrm{~mm}$ while average temperature is $10.4^{\circ} \mathrm{C}$.

\subsection{Geology and hydrogeology}

The watershed of Badove Lake geologically belongs to Vardar zone which represent the boundary line between the Dinaride zone and Serbian-Macedonian massif [5]. It consists of limestone, clastic formations (ophiolitik melange, sandstone, siltstone, mudstone), magmatic (gabbro-diabase, andesite, peridotite) and metamorphic (quartz-mica schist, chlorite schist, sericite schist, phyllite, gneiss, marble) rocks. The dam area is mostly composed of altered and fissured serpentinites [1] with subordinate phyllite schist, clastic formations and gabbrodiabase rocks. The above formations show low aquifer capacities and low permeability [6] besides karstic limestone and intergranular alluvial sediments. The yield of wells drilled in these later reaches up to $10 \mathrm{l} / \mathrm{s}$.

\section{Lake water balance}

All water balance equations are based on the premise that the difference between water inflow and water outflow over a given time period for the hydrologic system of a lake must equal to the change in water storage in that system $[7,8]$. All of the lake's water gains and losses and measuring the corresponding change in the lake level over the same period are taken into account in order to compute the lake water budget, as it appears in the following equation:

$\Delta \mathrm{V}=\left(\mathrm{V}_{\mathrm{P}}+\mathrm{V}_{\mathrm{R}}+\mathrm{V}_{\mathrm{S}}+\mathrm{V}_{\mathrm{GI}}\right)-\left(\mathrm{V}_{\mathrm{A}}+\mathrm{V}_{\mathrm{E}}+\mathrm{V}_{\mathrm{GO}}\right)$

where:

$\Delta \mathrm{V}=$ change in lake volume $\left(\mathrm{m}^{3}\right)$

$\mathrm{V}_{\mathrm{P}}=$ precipitation on the lake $\left(\mathrm{m}^{3}\right)$

$V_{R}=$ surface runoff from the catchment $\left(\mathrm{m}^{3}\right)$

$\mathrm{V}_{\mathrm{S}}=$ stream flow to the lake $\left(\mathrm{m}^{3}\right)$

$\mathrm{V}_{\mathrm{GI}}=$ groundwater inflow to the lake $\left(\mathrm{m}^{3}\right)$

$\mathrm{V}_{\mathrm{A}}=$ abstraction from the lake $\left(\mathrm{m}^{3}\right)$

$\mathrm{V}_{\mathrm{E}}=$ water evaporation from the lake $\left(\mathrm{m}^{3}\right)$

$\mathrm{V}_{\mathrm{GO}}=$ groundwater outflow from the lake $\left(\mathrm{m}^{3}\right)$

Data collection of the water balance components of the lake was carried out for 365 days. A water volume of $700,000 \mathrm{~m}^{3}$ was transferred from another lake to Badovc Lake in April 2014 because of the water lack in this later and this quantity of water was considered as an additional inflow component in the lake water balance. Direct measurments are applied for evaluation of bathymetry, water inflow, rainfalls, water level, while evaporation are calculated based on temperature, relative humidity, windy speed and insolation data obtained from the Hydrometerological Institute of Kosovo [2].

\subsection{Lake bathymetry}

The bathymetry survey of the lake bottom, that is the first one since closure of the lake (1965), was accomplished in October 2013. As a result, the bathymetry 
model of the lake was constructed along with volume and surface curves, figs. 2 and 3 . In addition, a sediment deposition of $1,000,000 \mathrm{~m}^{3}$ on the bottom of the lake (near the dam) was found, which represents a storage depletion of $3.9 \%$ of the total $\left(25,590,000 \mathrm{~m}^{3}\right)$ lake volume.

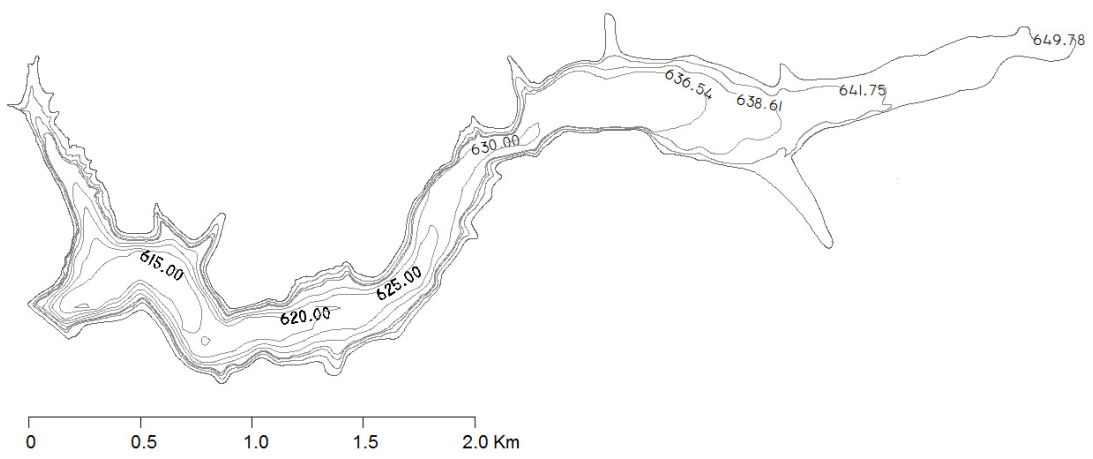

Figure 2: Bathymetric map of Badovc Lake, October 2013.

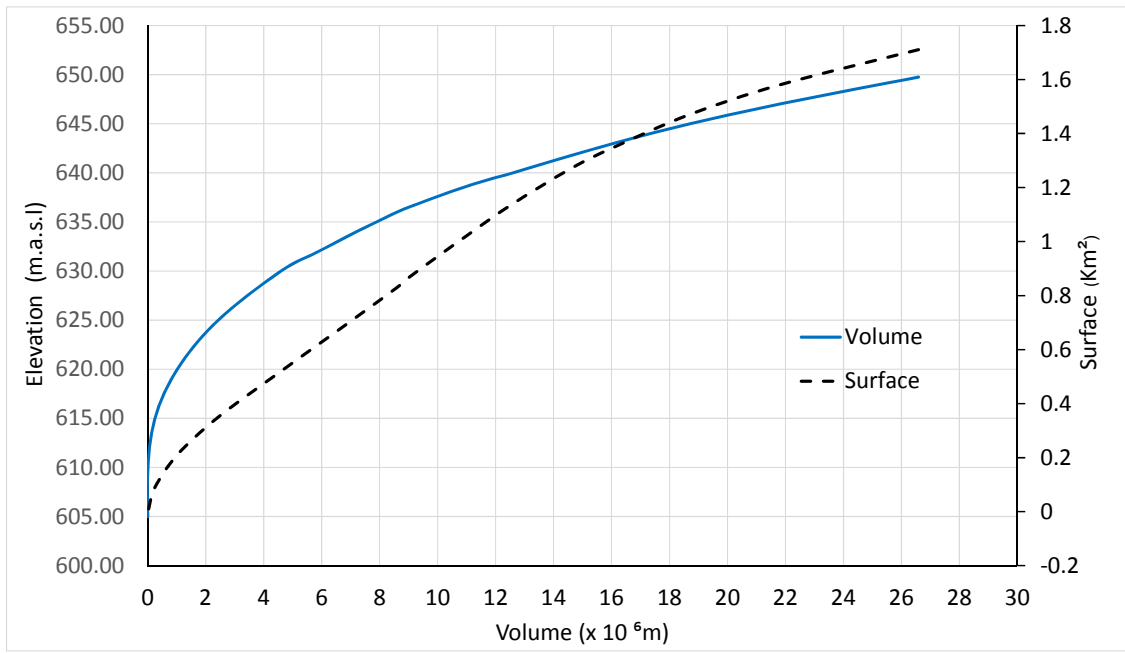

Figure 3: Volume and surface curves after bathymetric survey.

\subsection{Rainfall}

Four pluviometers are used to monitor the rainfalls for period 2013-2014 and their positioning is made in such a way to register the representative rainfall amount of the basin. Historical average rainfall for period 1947-1994 are $647.36 \mathrm{~mm}$, whereas the annual amount of rainfalls (table 1) for 2014, calculated according to the method of Thissenit, is $870.28 \mathrm{~mm}$ [9]. 
Table 1: Annual rainfall (in $\mathrm{mm}$ ) for the Badovc basin, year 2014.

\begin{tabular}{|l|c|c|c|c|}
\hline Pluviometer station & $\mathrm{P}_{1}$ & $\mathrm{P}_{2}$ & $\mathrm{P}_{3}$ & $\mathrm{P}_{4}$ \\
\hline Precipitation by station & 775.3 & 820.2 & 897.7 & 949.6 \\
\hline Basin precipitation & \multicolumn{5}{|c|}{870.28} \\
\hline
\end{tabular}

\subsection{Meteorological data}

The data on methorological (temperature, sunshine hours, relative humidity, wind speed) parameters are taken from the Hydrometeorology Institute of Kosovo [3]. Monthly temperatures and relative humidity ranged from $2^{\circ} \mathrm{C}$ (December) to $21.9^{\circ} \mathrm{C}$ (August) and from $67.6 \%$ (August) to $86.1 \%$ (December), respectively. Wind speed varied from $1 \mathrm{~m} / \mathrm{s}$ (September) to $2.3 \mathrm{~m} / \mathrm{s}$ (February), whereas sunshine varied from 1.3 hours/day (December) to 11.0 hours/day (August).

\subsection{Annual inflow into the lake}

Monitoring of water inflow into the Badovc Lake has not been continuous. The first measurements of water inflow were made during the dam design (19561962) which reported an annual water inflow of $32,482,080 \mathrm{~m}^{3}$ (or $1.03 \mathrm{~m}^{3} / \mathrm{sec}$ ) [2]. The annual inflow for 2014, that represents the second evaluation period of annual water inflow into Badovc Lake, was 22,577,663 $\mathrm{m}^{3}$ (table 2).

Table 2: Inflow volume to the Badovc Lake in $2014\left(\mathrm{~m}^{3}\right)$.

\begin{tabular}{|l|c|c|c|}
\hline Volume components & $\mathrm{V}_{\mathrm{S}}$ & $\mathrm{V}_{\mathrm{R}}$ & $\mathrm{V}_{\mathrm{P}}$ \\
\hline Annual & $18,198,579$ & $3,419,328$ & 959,756 \\
\hline Total inflow & \multicolumn{3}{|c|}{$22,577,663$} \\
\hline
\end{tabular}

\subsubsection{River flow to the lake $\left(V_{S}\right)$}

Badovc Lake has three independent perennial tributary rivers (Mramur, Slivovë and Androvina) that drain ultimately to the lake. The total volume of water that flow into the lake through these three rivers during the observation period (year 2014) was $18,198,579 \mathrm{~m}^{3}$ and represents about $83 \%$ of the total water inflow into the lake (table 2).

\subsubsection{Volume of runoff from the catchment $\left(V_{R}\right)$}

Besides water inflow from rivers and streams, another important component is direct overland flow to lake [10] which represents around $13 \%$ of the total runoff of the Badovc basin, which is $3,419,328 \mathrm{~m}^{3}$. The total inflow into the lake was artificially modified because in April 2014 a water volume of 700,000 $\mathrm{m}^{3}$ was added into the lake due to the decrease of water in the lake under the minimum level of utilization (table 2). 


\subsubsection{Volume of direct precipitation on the lake $\left(V_{P}\right)$}

Volume of water obtained from direct rain falling over the lake was estimated using average surface of the lake and depth of rainfall during the observation period. The total rainfall measured from the pluviometer of the lake during the year 2014 was $775.3 \mathrm{~mm}$. The corresponding volume of direct precipitation on the lake was $959,756 \mathrm{~m}^{3}$ (table 2).

\subsection{Outflow from the lake}

The factors affecting water outflow from the lake are: evaporation from the lake, water abstraction and infiltration of water from the lake bottom. The volume of water outflow due to evaporation and water abstraction in 2014 was $11,494,758$ $\mathrm{m}^{3}$ (table 3).

Table 3: Volume of water outflow from the Badove Lake in $2014\left(\mathrm{~m}^{3}\right)$.

\begin{tabular}{|l|c|c|c|}
\hline Volume components & $\mathrm{V}_{\mathrm{A}}$ & $\mathrm{V}_{\mathrm{GO}}$ & $\mathrm{V}_{\mathrm{E}}$ \\
\hline Annual & $10,550,615$ & 94,608 & 849,535 \\
\hline Total outflow & \multicolumn{3}{|c|}{$11,494,758$} \\
\hline
\end{tabular}

\subsubsection{Abstraction from the lake $\left(V_{A}\right)$}

The total volume of water abstracted from the lake over the entire observation period (2014) for household purposes was 10,550,615 $\mathrm{m}^{3}$ (table 3).

\subsubsection{Evaporation from the lake $\left(V_{E}\right)$}

The volume of water evaporated from the lake surface was calculated using Pennman equation (1) and results obtained were compared with values obtained using Meyer equation (2). The total evaporation from the lake surface was $849,535 \mathrm{~m}^{3}$ (table 3 ).

$$
\begin{aligned}
& E=0.35\left(0.5+0.54 u_{2}\right)\left(e_{s}-e_{0}\right) \\
& E=0.0269\left(1-\frac{u_{8}}{16}\right)\left(e_{s}-e_{0}\right)
\end{aligned}
$$

where:

E - Evaporation from water surface $(\mathrm{cm} /$ day)

$\mathrm{e}_{\mathrm{s}}$ - Pressure of saturated vapour above water surface $(\mathrm{mmHg})$

$\mathrm{e}_{0}$ - Current pressure of vapour above water surface $(\mathrm{mmHg})$

$\mathrm{u}_{2}$ - Speed of wind $(\mathrm{m} / \mathrm{sec})$

U8 - Speed of wind (cm/day)

\subsubsection{Groundwater inflow ( $\left.V_{G I}\right)$ and outflow ( $\left.V_{G O}\right)$}

Groundwater flow to or from the lake is often invoked to explain lake level changes that are not well understood on the basis of surface hydrology [7]. It is 
an important component of the lake water balance and the most difficult to quantify as it cannot be measured directly. The designed water infiltration from the lake dam was $94,608.00 \mathrm{~m}^{3}$ (tab 5) which is about 40 fold less that the difference $\left(3,738,905 \mathrm{~m}^{3}\right)$ calculated from the lake water balance (inflow minus outflow) for the year 2014. Such a difference in the lake water balance is considered as a groundwater outflow from the lake due to bottom infiltration through fracture system of the lake basement geological formations.

\subsection{Change in lake water volume in $2014(\Delta V)$}

Changes in lake water volume are calculated based on the fluctuations of water level in the lake which are a function of the balance between precipitation on the lake, runoff to the lake, evaporation, abstraction and groundwater outflow from the lake [11]. Water volume in Badove Lake on January 01, 2014 was $9,509,000 \mathrm{~m}^{3}$ while on December 12,2014 it was $16,853,000 \mathrm{~m}^{3}$ that corresponds to water level $637.15 \mathrm{~m}$ and $643.60 \mathrm{~m}$ (asl) and surface water area of $0.92 \mathrm{~km}^{2}$ and $1.38 \mathrm{~km}^{2}$, respectively, fig. 4. The lake volume in 2014 was increased with $7,344,000 \mathrm{~m}^{3}$, table 4 , fig. 5 .

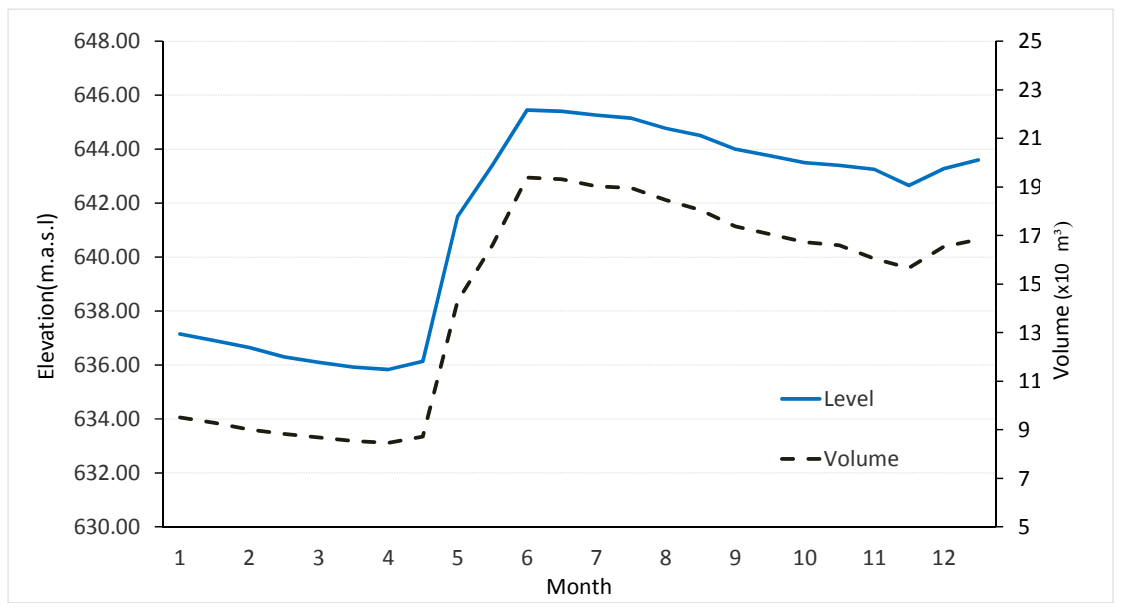

Figure 4: Level and volume variations for Badove Lake during 2014.

\section{Results and discussions}

The results of Badove lake water balance in 2014 showed that inflow volume into the lake was $22,577,663 \mathrm{~m}^{3}$, while outflow volume from the lake was $11,494,758 \mathrm{~m}^{3}$. As it can be seen in fig. 4, where level and volume variations during 2014 are shown, the volume change during 2014 was 7,344,000 $\mathrm{m}^{3}$ which is $3,738,905 \mathrm{~m}^{3}$ less than the difference between inflow and outflow water volumes (table 4). This water volume that represents around $17 \%$ of annual inflow into the lake for 2014, is considered as water loss from lake and can be 
Table 4: Monthy and annual water balance for the Badovc Lake, year 2014.

\begin{tabular}{|l|c|c|c|c|c|}
\hline \multirow{2}{*}{ Months } & $\begin{array}{c}\text { Level } \\
(\mathrm{mas})\end{array}$ & Inflow $\left(\mathrm{m}^{3}\right)$ & $\begin{array}{c}\text { Outflow } \\
\left(\mathrm{m}^{3}\right)\end{array}$ & $\begin{array}{c}\text { Volume } \\
\text { change in the } \\
\text { lake }\left(\mathrm{m}^{3}\right)\end{array}$ & $\begin{array}{c}\text { Groundwater } \\
\text { outflow } \\
(\text { losses })\left(\mathrm{m}^{3}\right)\end{array}$ \\
\cline { 2 - 6 } & 0 & 1 & 2 & 3 & $(1)-(2+3)$ \\
\hline January & 636.65 & 395,480 & 753,730 & $-497,000$ & $-138,750$ \\
\hline February & 636.10 & 348,500 & 709,970 & $-334,000$ & $-112,530$ \\
\hline March & 635.83 & 798,524 & 765,290 & $-213,000$ & $-106,233$ \\
\hline April & 641.50 & $7,125,400$ & 774,607 & $5,834,000$ & $-516,793$ \\
\hline May & 645.45 & $6,748,712$ & 960,103 & $5,087,000$ & $-701,610$ \\
\hline June & 645.26 & $1,318,836$ & $1,061,127$ & $-360,000$ & $-617,709$ \\
\hline July & 644.77 & 858,668 & $1,135,758$ & $-567,000$ & $-289,911$ \\
\hline August & 644.00 & 425,000 & $1,160,069$ & $-1,084,000$ & $-348,931$ \\
\hline September & 643.50 & 730,000 & $1,091,061$ & $-650,000$ & $-288,939$ \\
\hline October & 643.25 & 765,000 & $1,062,666$ & $-678,000$ & $-380,334$ \\
\hline November & 643.27 & $1,600,000$ & $1,007,155$ & 487,000 & $-105,845$ \\
\hline December & 643.60 & $1,463,542$ & $1,013,223$ & 319,000 & $-131,320$ \\
\hline Annual & & $22,577,663$ & $11,494,758$ & $7,344,000$ & $-3,738,905$ \\
\hline
\end{tabular}

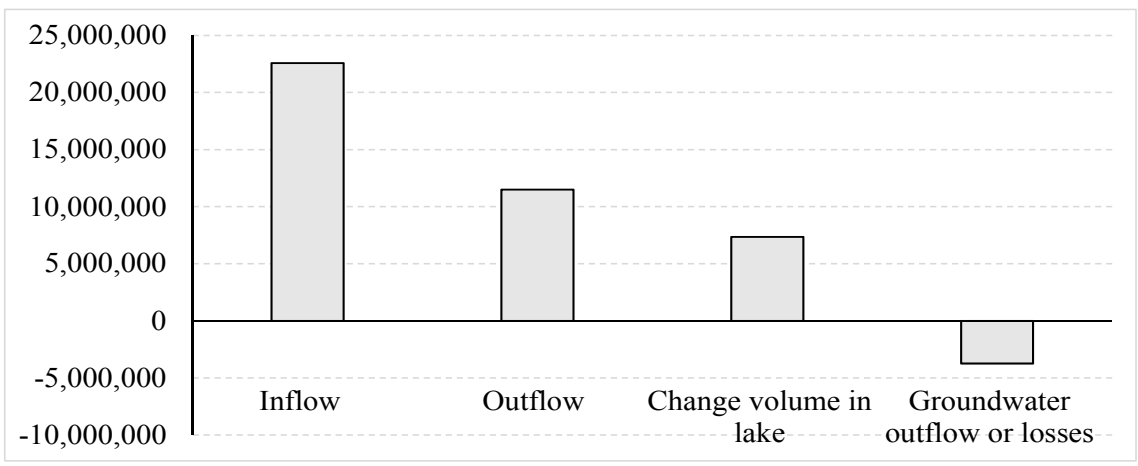

Figure 5: Annual water balance in Badovc Lake.

attributed to groundwater outflow due to water infiltration through cracks and tectonic zones that involved geological formations of lake bottom and beneath the dam. In the vicinity of the Badovc Lake there are three mines, but Hajvalia mine is the nearest (less than one $\mathrm{km}$ distance, fig. 6) one and a possible hydraulic communication between lake and this mine can be assumed. 


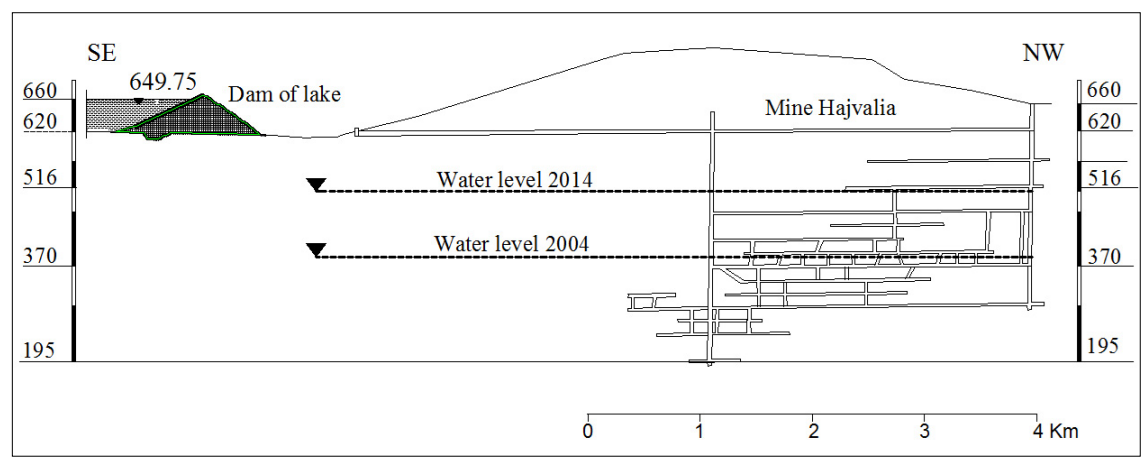

Figure 6: Cross section from the dam of Badove Lake to Hajvalia Mine.

In fact, a raise of $114 \mathrm{~m}$ of water level in abandoned Hajvalia mine was registered by the measurements performed from 2004 to 2014, fig. 7, [4]. Another indicator of water infiltration from the lake towards mine spaces is represented by the increase of $\mathrm{pH}$ value of mine water from 6.5 to 7.0 [4]. Neither the raise of level during period 2004-2014, nor the increase of $\mathrm{pH}$ value can be explained only with contribution of water infiltration from rainfalls. In fact, an amount of 2.5 million $\mathrm{m}^{3}$ water could be expected to infiltrate to mine from its catchment area $\left(1.5 \mathrm{~km}^{2}\right)$ during the period $2004-2014$. On the other hand, a volume over 5.0 million $\mathrm{m}^{3}$ water filling the empty spaces of the mine was calculated [4], which corresponds to the above water level raise in mine. Assuming that the whole infiltrated rainfall water drained somewhere prior to mine operation, we can consider that the above mine watering was related with groundwater outflow from the lake. This can also be supported by the fact that no consolidation measures of the formations beneath the dam were undertaken during the closure of the lake.

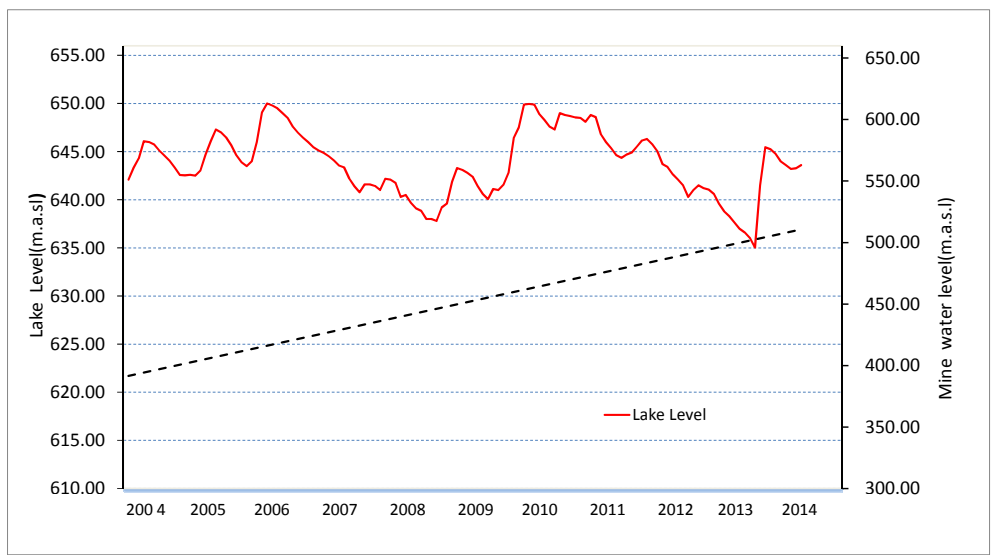

Figure 7: Variation of water level in Badovc Lake and in Hajvalia Mine (2004-2014). 


\section{Conclusions}

Badove catchment area is a typically closed centripetal river pattern, composed by low permeable, but highly tectonised and fissured geological formations.

A lack of $3,738,905 \mathrm{~m}^{3}$ water in the 2014 lake balance was found, that represents around $17 \%$ of annual inflow into the lake, is considered as water loss from lake due to groundwater outflow.

The raise of $114 \mathrm{~m}$ of water level in abandoned Hajvalia mine along with the increase of $\mathrm{pH}$ value of mine water from 6.5 to 7.0 are considered as two preleminary indicators in favor to a possible hydraulic communication between lake and this mine.

The missing consolidation measures favored crack system of bottom formations to be further activated during mine explosions enhancing the infiltration rate.

\section{References}

[1] Hyseni, S. Metalogenic particulars of polimetal mineralisations of mining field "Hajvali-Badovc-Kizhnicë", PhD Thesis, Tirane, 2000.

[2] Institute of Hydro-Economy "Jarosllav Çerni". Book 1. Characteristics of water resources, note 1 Geology and Hydrogeology, pp. 25-26, 1982.

[3] Hydrometerological Institute of Kosovo (HIK). Data on rainfalls for the period 2000-2014, 2014.

[4] Hajvalia Mine. Data from the diary on measuring of water level in the mine of Hajvalia, Trepça Mining, Mitrovice, Kosovo, 2014.

[5] Elezaj, Z. and Kodra, A. Geology of Kosovo, University Text Cataloging edition (CIP) ISBN 978-9951-00-068-0, Prishtinë, 2008.

[6] Independent Committee for Mines and Minerals (ICMM). Hydrogeological Map 1:200.000, Prishtinë, 2006.

[7] Gebreslase, M. SH., Hagos, Y. E. and Samuel, G., Lake Water Balance, Lambert Academic Publishing, Saabrucken, Germany, pp. 8-88, 2012.

[8] Radwan, G. A. Using Hydrological and Meteorological Data for Computing the Water Budget in lake Qarum, Egypt. National Institute of Oceanography and Fisheries, Egypt, 2009.

[9] Show, E. M. Hydrology in practice, Taylor and Francis E-Library, England, p. 628, 2005.

[10] Brian, P., Neff and Jason, R., Killian. The Great Lakes Water Balance: Data Availability and Annotated Bibliography of Sepected References. Water Resources Investigations Report 02-4296, 2003.

[11] Van der Camp, G., Keir, D. and Evans, M. Long-term water level changes in closed basin lakes of the Canadian prairies. Canadian Water Resources Association Journal Department of Earth Sciences and Technology, 2008. 